\title{
Complex secondary metabolites from Ludwigia leptocarpa with potent antibacterial and antioxidant activities
}

\author{
Florence Déclaire Mabou ${ }^{1}$, Jean-de-Dieu Tamokou, ${ }^{2, *}$, David Ngnokam ${ }^{1, *}$, \\ Laurence Voutquenne-Nazabadioko ${ }^{3}$, Jules-Roger Kuiate ${ }^{2}$, Prasanta Kumar Bag ${ }^{4}$ \\ ${ }^{1}$ Laboratory of Environmental and Applied Chemistry, Department of Chemistry, Faculty of Science, University of Dschang, \\ Dschang, Cameroon; \\ ${ }^{2}$ Laboratory of Microbiology and Antimicrobial Substances, Department of Biochemistry, Faculty of Science, University of \\ Dschang, Dschang, Cameroon; \\ ${ }^{3}$ Groupe Isolement et Structure, Institut de Chimie Moléculaire de Reims (ICMR), Reims, France; \\ ${ }^{4}$ Department of Biochemistry, University of Calcutta, Kolkata, India.
}

\begin{abstract}
Summary Diarrhea continues to be one of the most common causes of morbidity and mortality among infants and children in developing countries. The aim of the present study was to evaluate the antibacterial and antioxidant activities of extracts and compounds from Ludwigia leptocarpa, a plant traditionally used for its vermifugal, anti-dysenteric, and antimicrobial properties. A methanol extract was prepared by maceration of the dried plant and this was successively extracted with ethyl acetate to obtain an EtOAc extract and with n-butanol to obtain an n-BuOH extract. Column chromatography of the EtOAc and $\mathrm{n}-\mathrm{BuOH}$ extracts was followed by purification of different fractions, leading to the isolation of 10 known compounds. Structures of isolated compounds were assigned on the basis of spectral analysis and by comparison to structures of compounds described in the literature. Antioxidant activity was evaluated using 1,1-diphenyl-2-picrylhydrazyl (DPPH) and gallic acid equivalent antioxidant capacity (GAEAC) assays. Antibacterial activity was assessed with the minimum inhibitory concentration (MIC) and minimum bactericidal concentration (MBC) with respect to strains of a Gram-positive bacterium, Staphylococcus aureus (a major cause of community and hospital-associated infection), and Gram-negative multidrug-resistant bacteria, Vibrio cholerae (a cause of cholera) and Shigella flexneri (a cause of shigellosis). All of the extracts showed different degrees of antioxidant and antibacterial activities. $2 \beta$-hydroxyoleanolic acid, (2R,3S,2"'S)-3"',4',4"',5,5",7,7"'-heptahydroxy3,8 "-biflavanone, and luteolin-8-C-glucoside displayed the most potent antibacterial and antioxidant properties, and these properties were in some cases equal to or more potent than those of reference drugs. Overall, the present results show that L. leptocarpa has the potential to be a natural source of anti-diarrheal and antioxidant products, so further investigation is warranted.
\end{abstract}

Keywords: Ludwigia leptocarpa, Onagraceae, triterpenoids, flavonoids, antibacterial, antioxidant

*Address correspondence to:

Dr Jean-de-Dieu Tamokou, Laboratory of Microbiology and Antimicrobial Substances, Department of Biochemistry, Faculty of Science, University of Dschang, P O. Box 67 Dschang, Cameroon.

E-mail: jtamokou@yahoo.fr; jean.tamokou@univ-dschang.org

Dr. David Ngnokam, Laboratory of Environmental and Applied Chemistry, Department of Chemistry, Faculty of Science, University of Dschang, P O. Box 67, Dschang, Cameroon.

E-mail: dngnokam@yahoo.fr

\section{Introduction}

In developing countries, and particularly in Africa, poor sanitation exposes people to a wider array of microbial pathogens, increasing their susceptibility to bacterial infections (1). Each year, 3 million children are reported to die of diarrheal diseases. Cholera is a leading diarrheal disease in terms of its severity and outcomes. Several epidemics of cholera have been 
reported in different parts of Cameroon and abroad (25). Vibrio cholerae strains belonging to the $\mathrm{O} 1$ and O139 serogroups cause epidemics and pandemics of cholera $(6,7)$. Over the past few years, reported cases of cholera have increased steadily, numbering more than 300,000 cases and including more than 7,500 deaths in 2010 (8). As populations of poor countries continue to coalesce in mega-cities with low levels of sanitation and people move rapidly around the globe, new and more virulent strains of $V$. cholerae are expected to disseminate more rapidly $(9,10)$. This makes cholera one of the most rapidly fatal infectious illnesses known.

The continuous emergence of multi-drug-resistant (MDR) Vibrio cholerae strains drastically reduces the efficacy of our antibiotic armory and, consequently, increases the frequency of therapeutic failure $(11,12)$. In many regions affected by this pathogen, local and indigenous plants are often the only available means of treating such infections. Among the known plant species on Earth (estimated at 250,000-500,000), only a small fraction have been investigated for the presence of antimicrobial compounds and only $1-10 \%$ of plants are used by humans $(13,14)$. Natural plant products also act as antioxidants. These include phenolic compounds, alkaloids, terpenoids, and essential oils. Plant-based antioxidant compounds (15) play a defensive role by preventing the generation of free radicals and hence are extremely beneficial to alleviating infectious diseases that generate free radicals as well as diseases caused by oxidative stress such as cardiovascular diseases, diabetes, inflammation, degenerative diseases, cancer, anemia, and ischemia (16).

Ludwigia leptocarpa (Nutt) Hara (Onagraceae or Oenotheraceae) is a herbaceous plant species that is also readily found in North America and in tropical Africa (17). In traditional medicine in Nigeria, an infusion of the plant is part of a mixture used to treat rheumatism (18). A leaf infusion has laxative, vermifugal, and antidysenteric properties. Previous studies of this genus have revealed the presence of flavonoids $(19,20)$, cerebrosides, and triterpenoids (20,21). A study recently reported that alcoholic extracts of the leaves of $L$. octovalvis, L. abyssinica, and L. decurrens potentially have antioxidant, antibacterial, and antifungal activities $(22,23)$. To the extent known, no study has reported on the antioxidant and antibacterial properties of $L$. leptocarpa with respect to bacterial strains causing diarrhea. Hence, the aim of this study was to investigate the antibacterial and antioxidant properties of extracts and compounds from L. leptocarpa.

\section{Materials and Methods}

\subsection{Experimental}

IR spectra were recorded with a Shimadzu FT-IR8400S (Shimadzu, France) spectrophotometer. ${ }^{1} \mathrm{H}$ (500
$\mathrm{MHz})$ and ${ }^{13} \mathrm{C}(125 \mathrm{MHz})$ nuclear magnetic resonance (NMR) spectra were recorded on a BRUKER Avance DRX-500 spectrometer (Bruker, Wissembourg, France) equipped with a BBFO $+5 \mathrm{~mm}$ probe. ${ }^{1} \mathrm{H}(600 \mathrm{MHz})$ and ${ }^{13} \mathrm{C}(150 \mathrm{MHz}) \mathrm{NMR}$ spectra were recorded on a BRUKER Avance III-600 spectrometer (Bruker, Wissembourg, France) equipped with a cryoplatform using $\mathrm{CD}_{3} \mathrm{OD}$, with tetramethylsilane (TMS) as the internal standard. Time-of-flight electrospray ionization mass spectrometry (TOF-ESIMS) and highresolution time of flight electrospray ionization mass spectrometry (HR-TOFESIMS) experiments were performed using a Micromass Q-TOF micro instrument (Manchester, UK) with an electrospray source. The samples were introduced by direct infusion in a solution of methanol $(\mathrm{MeOH})$ at a rate of $5 \mu \mathrm{L} \mathrm{min}{ }^{-1}$. Column chromatography was performed on Merck silica gel (VWR, France) 60 (70-230 mesh) and gel permeation chromatography was performed on Sephadex LH-20 (VWR, France), while thin layer chromatography (TLC) was carried out on silica gel GF254 pre-coated plates with detection accomplished by spraying with $50 \%$ $\mathrm{H}_{2} \mathrm{SO}_{4}$ followed by heating at $100^{\circ} \mathrm{C}$ or by visualization with an ultra-violet (UV) lamp at 254 and $365 \mathrm{~nm}$.

\subsection{Plant material}

L. leptocarpa plants were collected in the village of Foto (Menoua Division, Western region of Cameroon), in April 2011. Authentication was performed by Victor Nana, a botanist at the Cameroon National Herbarium, Yaoundé, where a voucher specimen ( $\left.\mathrm{N}^{\circ} 38782 / \mathrm{HNC}\right)$ was deposited.

\subsection{Extraction and isolation}

Dried L. leptocarpa $(4 \mathrm{~kg})$ was extracted with $\mathrm{MeOH}$ at room temperature for 3 days, and the extract was concentrated to dryness under reduced pressure to yield a dark crude extract (102 g). Part of the residue obtained $(97 \mathrm{~g})$ was suspended in water $(200 \mathrm{~mL})$ and successively extracted with ethyl acetate (EtOAc) and n-butanol $(n-\mathrm{BuOH})$. The result was concentrated to dryness under reduced pressure to respectively yield EtOAc $(20 \mathrm{~g})$ and $n$-BuOH (40 g) extracts.

In accordance with antimicrobial and antioxidant assays, the EtOAc and $n$-BuOH extracts were submitted to further separation and purification. Part of the EtOAc extract (15 g) was purified over a silica gel column and eluted with hexane containing increasing concentrations of EtOAc $(10 \%, 20 \%, 30 \%, 40 \%, 50 \%, 60 \%, 70 \%$, and $80 \%$ ). The purified extracted was also eluted with EtOAc containing increasing concentrations of $\mathrm{MeOH}$ (10\% and 20\%). Six fractions were obtained: A, B, C, D, E, and F. Fraction D (1.7 g) was purified over a silica gel column and eluted with a hexane-EtOAc mixture (7:3) to yield compounds 1 and 2 (17 mg and $22 \mathrm{mg}$, 
respectively). Fraction E (3.1 g) was purified over a silica gel column and eluted with a hexane-EtOAc mixture (6:4) to yield compound 3 (17 mg). Part of the $n$-BuOH extract (30 g) was purified over a silica gel column and eluted with EtOAc containing increasing concentrations of $\mathrm{MeOH}(10 \%, 20 \%, 30 \%, 40 \%$, and $50 \%$ ). Five fractions $\left(\mathrm{G}_{1}-\mathrm{G}_{5}\right)$ were obtained. Fraction $\mathrm{G}_{1}$ (2.5 g) was purified over a silica gel column and eluted with EtOAc to yield the compounds 4 (19 mg) and 5 (16 mg). Fraction $\mathrm{G}_{2}$ (3.1 g) was purified over a silica gel column and eluted with an EtOAc-MeOH mixture (8.5:1.5) to yield compounds 5 (25 mg) and $\mathbf{6}(13 \mathrm{mg})$. Fractions $\mathrm{G}_{3}$ and $\mathrm{G}_{4}(5.4 \mathrm{~g})$ were combined and purified over a silica gel column; the fractions were then eluted with an EtOAc-MeOH-H2O mixture $(8: 1: 1)$ to yield the compounds 7 (38 $\mathrm{mg})$ and $8(24 \mathrm{mg})$. Fraction G5 ( $2.5 \mathrm{~g})$ was purified over a silica gel column and eluted with an EtOAc-MeOH- $\mathrm{H}_{2} \mathrm{O}$ mixture $(7: 2: 1)$ to yield the compounds 9 (66 mg) and $\mathbf{1 0}$ (40 mg).

Oleanolic acid (1): white amorphous powder from hexane-EtOAc; $\mathrm{C}_{30} \mathrm{H}_{48} \mathrm{O}_{3}$.

$2 \beta$-hydroxyoleanolic acid (2): white amorphous powder from hexane-EtOAc; $\mathrm{C}_{30} \mathrm{H}_{48} \mathrm{O}_{4}$.

$(2 R, 3 S, 2 " S)-3$ "',4',4"',5,5", 7,7"'-heptahydroxy-3,8"biflavanone (3): white amorphous powder from hexaneEtOAc; $\mathrm{C}_{30} \mathrm{H}_{22} \mathrm{O}_{11}$; high resolution electron impact mass spectrometry (HRESIMS, positive-ion mode) $\mathrm{m} / \mathrm{z}$ : $581.1057[\mathrm{M}+\mathrm{Na}]^{+}$(calcd. for $\mathrm{C}_{30} \mathrm{H}_{22} \mathrm{O}_{11} \mathrm{Na}: 581.1060$ ).

Ellagic acid (4): yellow powder from EtOAc; $\mathrm{C}_{14} \mathrm{H}_{6} \mathrm{O}_{8}$.

$\beta$-sitosterol-3- $O$ - $\beta$-D-glucopyranoside (5): white amorphous powder from $\mathrm{EtOAcC}_{35} \mathrm{H}_{60} \mathrm{O}_{6}$.

Luteolin-8-C-glucoside (6): yellow amorphous powder from $\mathrm{EtOAcC}_{21} \mathrm{H}_{20} \mathrm{O}_{11}$.

28 - $O-\beta$ - D - x y l o p y r a n o s y $1-(1 \rightarrow 4)-\alpha-\mathrm{L}$ rhamnopyranosyl- $(1 \rightarrow 2)$-[ $\alpha$-L-arabinopyranosyl- $(1 \rightarrow 3)]$ 4-O-(3'-hydroxybutanoyloxy-3-hydroxybutanoyloxy)$\beta$-D-fucopyranosyl zanhic acid (7): white amorphous solid from EtOAc; $\mathrm{C}_{60} \mathrm{H}_{94} \mathrm{O}_{27}$; HRESIMS (positive-ion mode) $\mathrm{m} / \mathrm{z}: 1269.5870[\mathrm{M}+\mathrm{Na}]^{+}$(calcd. for $\mathrm{C}_{60} \mathrm{H}_{94} \mathrm{O}_{27} \mathrm{Na}$ : 1269.5880).

3-O- $\beta$-D-glucopyranosyl-28- $O-\beta$-D-xylopyranosyl$(1 \rightarrow 4)-\alpha-L-r h a m n o p y r a n o s y 1-(1 \rightarrow 2)-4-O-\left(3^{\prime}-\right.$ hydroxybutanoyloxy-3-hydroxybutanoyloxy)- $\beta$-Dfucopyranosyl medicagenic acid (8): white amorphous solid from EtOAc; $\mathrm{C}_{61} \mathrm{H}_{96} \mathrm{O}_{27}$; HRESIMS (positive-ion mode) $\mathrm{m} / \mathrm{z}: 1283.6044[\mathrm{M}+\mathrm{Na}]^{+}$(calcd. for $\mathrm{C}_{61} \mathrm{H}_{96} \mathrm{O}_{27} \mathrm{Na}$ : 1283.6037).

3- $O$ - $\beta$-D-glucopyranosyl-28- $O-\beta$-D-xylopyranosyl$(1 \rightarrow 4)-\alpha-\mathrm{L}-\mathrm{rh}$ a m nopyranosyl $(1 \rightarrow 2)-[\alpha-\mathrm{L}-$ arabinopyranosyl- $(\rightarrow 3)]-4-O-(3$ '-hydroxybutanoyloxy3 -hydroxybutanoyloxy)- $\beta$-D-fucopyranosyl zanhic acid (9): white amorphous solid from EtOAc; $\mathrm{C}_{66} \mathrm{H}_{104} \mathrm{O}_{32}$; HRESIMS (positive-ion mode) $\mathrm{m} /$ z: $1431.6395[\mathrm{M}+\mathrm{Na}]^{+}$(calcd. for $\mathrm{C}_{66} \mathrm{H}_{104} \mathrm{O}_{32} \mathrm{Na}$ : 1431.6408).

3 - $O$ - $\beta$ - D - g l u copyranos y $1-(1 \rightarrow 4)-\beta$ - D - glucopyranosyl-28- $O$ - $\beta$-D-xylopyranosyl- $(1 \rightarrow 4)-\alpha-$ L-rhamnopyranosyl- $(1 \rightarrow 2)$-[ $\alpha$-L- arabinopyranosyl$(1 \rightarrow 3)]-4-O-\left(3^{\prime}-\right.$ h y d r o x y bu t a no y lox y - 3 hydroxybutanoyloxy)- $\beta$-D-fucopyranosyl zanhic acid (10): white amorphous solid from EtOAc; $\mathrm{C}_{72} \mathrm{H}_{114} \mathrm{O}_{37}$; HRESIMS (positive-ion mode) m/z: 1593.6927[M + $\mathrm{Na}]^{+}$(calcd. for $\mathrm{C}_{72} \mathrm{H}_{114} \mathrm{O}_{37} \mathrm{Na}: 1593.6937$ ).

\subsection{Antibacterial assay}

\subsubsection{Microorganisms}

A total of six bacterial strains were tested for their susceptibility to compounds and these strains were from our laboratory collection (kindly provided by Dr. T. Ramamurthy, NICED, Kolkata). Among the clinical strains of Vibrio cholerae used in this study, strain NB2 belongs to the O1 serotype and strain SG24(1) belongs to the O139 serotype. These strains are able to produce cholera toxin and hemolysin $(24,25)$. The other strains used in this study were non-O1 and non-O139 strains of $V$. cholerae (strains CO6 and PC2) (24) and strains of Shigella flexneri (26). The non-O1 and non-O139 strains of $V$. cholerae were positive for hemolysin production but negative for cholera toxin production (24). An American Type Culture Collection (ATCC) strain of Staphylococcus aureus, ATCC 25923, was used for quality control. The bacterial strains were maintained on an agar slant at $4^{\circ} \mathrm{C}$ and subcultured on appropriate fresh agar plates $24 \mathrm{~h}$ prior to any antibacterial testing. Mueller Hinton Agar (MHA) was used to activate bacteria. Mueller Hinton Broth (MHB) was used to determine minimum inhibitory concentrations (MICs) and nutrient agar (HiMedia) was used to determine minimum bactericidal concentrations (MBCs).

\subsubsection{Determination of MICs and $M B C s$}

MICs and MBCs of extracts/compounds were assessed using the broth microdilution method recommended by the National Committee for Clinical Laboratory Standards $(27,28)$ with slight modifications. Each test sample was dissolved in dimethylsulfoxide (DMSO, Fisher chemicals) to yield a stock solution. Ninetysix-well round-bottom sterile plates were prepared by dispensing $180 \mu \mathrm{L}$ of the inoculated broth $\left(1 \times 10^{6} \mathrm{CFU} /\right.$ $\mathrm{mL}$ ) into each well. A $20 \mu \mathrm{L}$ aliquot of a compound was added. The concentration of the tested samples varied from 0.125 to $1,024 \mu \mathrm{g} / \mathrm{mL}$. The final concentration of DMSO in each well was $<1 \%$ [preliminary analyses with $1 \%(\mathrm{v} / \mathrm{v})$ DMSO did not inhibit the growth of the test organisms]. Dilutions of ampicillin (SigmaAldrich, Steinheim, Germany) and tetracycline (SigmaAldrich, Steinheim, Germany) served as positive controls, while broth with $20 \mu \mathrm{L}$ of DMSO was used as a negative control. Plates were covered and incubated 
for $24 \mathrm{~h}$ at $37^{\circ} \mathrm{C}$. After incubation, MICs were read visually; bacteria were plated on nutrient agar (Conda, Madrid, Spain) and incubated at $37^{\circ} \mathrm{C}$ for $24 \mathrm{~h}$. The lowest concentrations that yielded no growth after this subculturing served as the MBC.

\subsection{Antioxidant assay}

\subsubsection{DPPH free radical scavenging assay}

The free radical scavenging activity of extracts as well as their isolated compounds was assessed in accordance with the methods of Brand-Williams et al. (29) with slight modifications. Briefly, different concentrations (10 to $2,000 \mu \mathrm{g} / \mathrm{mL}$ ) of extracts or compounds and vitamin C (Sigma-Aldrich, Steinheim, Germany) were thoroughly mixed with $3 \mathrm{~mL}$ of a methanolic DPPH solution $(20 \mathrm{mg} / \mathrm{L})$ in test tubes and the resulting solution was allowed to stand for 30 minutes at room temperature before the optical density (OD) was measured at $517 \mathrm{~nm}$. The measurement was repeated 3 times and an average of those readings was determined. The percentage radical scavenging activity was calculated using the following formula: \% scavenging $[\mathrm{DPPH}]=\left[\left(\mathrm{A}_{0}-\mathrm{A}_{1}\right) / \mathrm{A}_{0}\right] \times 100$. Here, $A_{0}$ is the absorbance of the control and $A_{1}$ is the absorbance in the presence of the sample. The $\mathrm{IC}_{50}$ was determined from a graph obtained using standard vitamin $\mathrm{C}$ by using the formula " $\mathrm{y}=\mathrm{mx}+\mathrm{c}$ " for the slope of the graph.

\subsubsection{Gallic acid equivalent antioxidant capacity (GAEAC) assay}

A GAEAC assay was performed as previously described (30) with slight modifications. In a quartz cuvette, $20 \mu \mathrm{L}$ of laccase ( $1 \mathrm{mM}$ stock solution), $20 \mu \mathrm{L}$ of a test sample, and $10 \mu \mathrm{L}$ of ABTS (2,2'-azinobis(3ethylbenzothiazoline-6-sulfonic acid) (74 $\mathrm{mM}$ of stock solution) were added to $950 \mu \mathrm{L}$ of an acetate buffer $(\mathrm{pH}=5.0,100 \mathrm{mM})$. The laccase was purified from Sclerotinia sclerotiorum according to a previously described protocol (31). The sample concentrations in the assay mixture were $800,400,200,100$, and $10 \mu \mathrm{g} / \mathrm{mL}$ for the extracts and $200,100,50,25$, and $125.5 \mu \mathrm{g} / \mathrm{mL}$ for the isolated compounds. The content of the generated $\mathrm{ABTS}^{\bullet+}$ radical was measured at $420 \mathrm{~nm}$ after reaction for $240 \mathrm{~s}$ and this measurement was converted to the gallic acid equivalent using a calibration curve (Pearson's correlation coefficient: $r=0.996$ ) created with $0,4,10$, $14,28,56$, and $84 \mu \mathrm{M}$ of gallic acid rather than Trolox. Experiments were done in triplicate.

\subsection{Statistical analysis}

Data were analyzed using one-way analysis of variance followed by the Waller-Duncan post-hoc test. Results are expressed as the mean \pm standard deviation (SD). $p<0.05$ was considered to indicate a significant difference. All analyses were performed using the software Statistical Package for Social Sciences (SPSS, version 12.0).

\section{Results and Discussion}

\subsection{Chemical analysis}

In accordance with antibacterial assays of the $\mathrm{MeOH}$, EtOAc, and $n$-BuOH extracts, the EtOAc and $n$-BuOH extracts were further separated and purified. This led to the isolation of 10 compounds. Structures (Figure 1) of these compounds have been assigned on the basis of spectroscopic data $\left({ }^{1} \mathrm{H}\right.$ and ${ }^{13} \mathrm{C} \mathrm{NMR},{ }^{1} \mathrm{H}-$ ${ }^{1} \mathrm{H}$ COSY, HSQC, HMBC, ROESY, and NOESY), mass spectra, and by comparison of those compounds to compounds described in the literature. Hence, the isolated compounds were identified as oleanolic acid (1) (32); 2 $\beta$-hydroxyoleanolic acid (2) (32); (2R,3S,2"S)3"',4',4"',5,5",7,7"-heptahydroxy-3,8"-biflavanone (3) (33); ellagic acid (4) (34); 3- $O$ - $\beta$-D-glucopyranosyl- $\beta$-sitosterol (5) (35); luteolin-8-C-glucoside (6) (36); $28-O-\beta$-Dxylopyranosyl- $(1 \rightarrow 4)-\alpha$-L-rhamnopyranosyl- $(1 \rightarrow 2)$ - $[\alpha-\mathrm{L}-$ arabinopyranosyl-( $1 \rightarrow 3)]-4-O-(3$ '-hydroxybutanoyloxy3 -hydroxybutanoyloxy)- $\beta$-D-fucopyranosyl zanhic acid (7) (21); 3-O- $\beta$-D-glucopyranosyl-28-O- $\beta$-Dxylopyranosyl- $(1 \rightarrow 4)-\alpha$-L-rhamnopyranosyl- $(1 \rightarrow 2)-4$ $O$-(3'-hydroxybutanoyloxy-3-hydroxybutanoyloxy)- $\beta$ D-fucopyranosyl medicagenic acid (8) $(21) ; 3-O-\beta$-Dglucopyranosyl-28- $O-\beta$-D-xylopyranosyl- $(1 \rightarrow 4)-\alpha$-Lrhamnopyranosyl $(1 \rightarrow 2)$-[ $\alpha$-L-arabinopyranosyl- $(\rightarrow 3)]$ 4-O-(3'-hydroxybutanoyloxy-3-hydroxybutanoyloxy)$\beta$-D-fucopyranosyl zanhic acid (9) (20); and 3- $O$ - $\beta$-Dglucopyranosyl- $(1 \rightarrow 4)-\beta$-D-glucopyranosyl-28- $O-\beta$-Dxylopyranosyl- $(1 \rightarrow 4)-\alpha$-L-rhamnopyranosyl- $(1 \rightarrow 2)-[\alpha-\mathrm{L}-$ arabinopyranosyl-( $1 \rightarrow 3)]-4-O-(3$ '-hydroxybutanoyloxy3-hydroxybutanoyloxy)- $\beta$-D-fucopyranosyl zanhic acid (10) (21).

\subsection{Antibacterial activity}

The susceptibility pattern and inhibition parameters of the tested organisms to the extracts and isolated compounds are indicated below (Table 1). Wells containing a concentration of $64-512 \mu \mathrm{g} / \mathrm{mL}$ of $\mathrm{MeOH}$, EtOAc, and $n-\mathrm{BuOH}$ extracts inhibited the visible growth of all bacterial species. The most sensitive bacterial species were $S$. aureus and $S$. flexneri, while $V$. cholerae SG24(1) and $V$. cholerae NB2 were the species that were most resistant to the tested samples. All 3 plant extracts displayed less antibacterial activity than tetracycline. However, these extracts were active against $V$. cholerae NB2, $V$. cholerae $\mathrm{PC} 2$, and $S$. flexneri which were not sensitive to ampicillin. The antimicrobial activity of a plant extract was considered to be good if its MIC was less than $100.0 \mu \mathrm{g} / \mathrm{mL}$, 


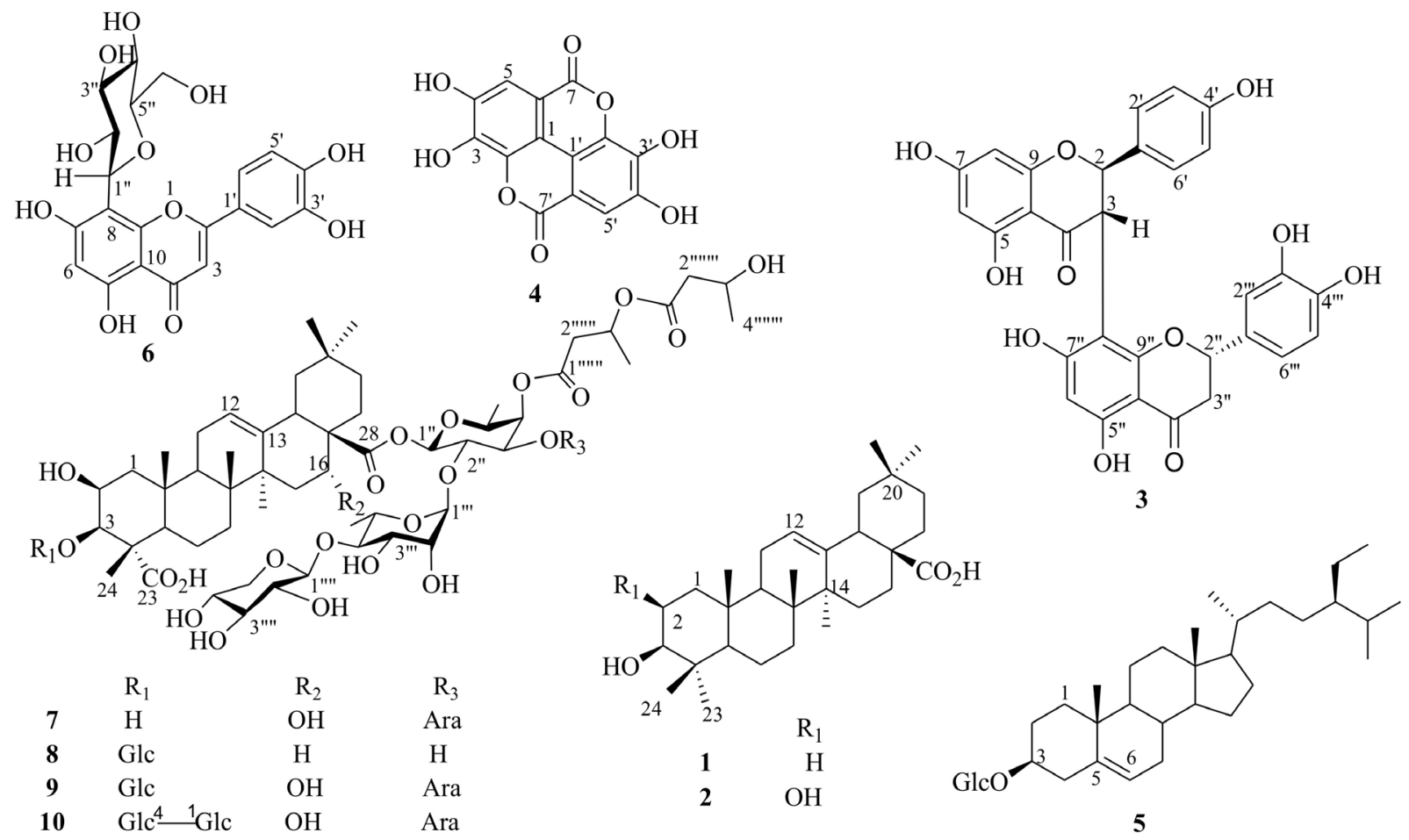

Figure 1. Structures of compounds isolated from the plant L. leptocarpa.

moderate if its MIC was from 100.0 to $500.0 \mu \mathrm{g} / \mathrm{mL}$ and poor if its MIC was over $500.0 \mu \mathrm{g} / \mathrm{mL}$ (37). Hence, the $\mathrm{MeOH}, \mathrm{EtOAc}$, and $n$-BuOH extracts of $L$. leptocarpa exhibited good activity against $S$. aureus, with an MIC of $64 \mu \mathrm{g} / \mathrm{mL}$, whereas only the $\mathrm{MeOH}$ extract displayed poor activity against $V$. cholerae SG24(1). The present results for extracts of L. leptocarpa indicated that this plant species is a potential source of antibacterial agents. This in vitro study corroborated a previous study that found that alcoholic extracts of L. octovalvis, $L$. abyssinica, and $L$. decurrens leaves inhibited Staphylococcus aureus $(22,23,38)$.

Compound 3 had the lowest MICs and MBCs, 2 $\mu \mathrm{g} / \mathrm{mL}$, for $S$. aureus; this compound has promise as an antibacterial since it was more potent at inhibiting S. aureus than the reference antibacterials ampicillin (MIC of $16 \mu \mathrm{g} / \mathrm{mL}$ and $\mathrm{MBC}$ of $16 \mu \mathrm{g} / \mathrm{mL}$ ) and tetracycline (MIC of $16 \mu \mathrm{g} / \mathrm{mL}$ and MBC of $128 \mu \mathrm{g} / \mathrm{mL}$ ) were. However, a MeOH extract had the highest MIC, 512 $\mu \mathrm{g} / \mathrm{mL}$, for $V$. cholerae $\mathrm{SG} 24(1)$ while a $\mathrm{MeOH}$ extract had the highest MBC, $512 \mu \mathrm{g} / \mathrm{mL}$, for $V$. cholerae SG24(1), V. cholerae CO6, and V. cholerae PC2. A lower MBC or MIC $(\leq 4)$ means that a minimum amount of the plant extract or isolated compound was needed to kill the bacterial species while a higher value means that a comparatively higher concentration of the extract or compound was needed to control of the microorganism (39).

Ranked in order of antibacterial activity, compound 3 isolated from L. leptocarpa had the most potent antibacterial activity, followed by compound $\mathbf{6}$, compound $\mathbf{2}$, compound $\mathbf{4}$, compounds 8 and $\mathbf{9}$, compound 10, compound $\mathbf{7}$, and then compound $\mathbf{1}$. Compounds $3,6,2,4,8,9$, and 10 were active against all of the tested pathogens whereas compound $\mathbf{1}$ was active only against $S$. flexneri and $S$. aureus. No activity was noted for compound $\mathbf{5}$ (results not shown). Antimicrobial cut-off points have been defined by several authors to enable an understanding of the antimicrobial potential of pure compounds. Activity of a compound is classified as: significant activity ( $\mathrm{MIC}<10 \mu \mathrm{g} / \mathrm{mL}$ ), moderate activity $(10<$ MIC $\leq 100 \mu \mathrm{g} / \mathrm{mL})$, and low activity (MIC $>100 \mu \mathrm{g} / \mathrm{mL})(40,41)$. Accordingly, compound 3 had significant antibacterial activity against $V$. cholerae CO6, V. cholerae NB2, V. cholerae PC2, S. flexneri, and $S$. aureus while compound 6 had significant antibacterial activity against Shigella flexneri SDINT and Staphylococcus aureus ATCC 25923. The strains of $V$. cholerae NB2, PC2 $(24,25)$ and Shigella flexneri (26) included in the present study were MDR clinical isolates and these were resistant to commonly used drugs such as ampicillin, streptomycin, tetracycline, nalidixic acid, furazolidone, and co-trimoxazole. However, most of the tested samples displayed antibacterial activity against these microbial strains, suggesting that their administration may represent an alternative treatment for $V$. cholerae, the cause of the dreadful disease cholera, and S. flexneri, the cause of shigellosis. Given the medical importance of the tested bacteria, the present results offer promise in terms of developing new antibacterials. The antibacterial activity of oleanolic acid, ellagic acid, and $2 \beta$-hydroxyoleanolic acid coincide with 
Table 1. Antibacterial activity (MIC and $\mathrm{MBC}$ in $\mu \mathrm{g} / \mathrm{ml}$ ) of extracts, isolated compounds, and reference antibacterials

\begin{tabular}{|c|c|c|c|c|c|c|c|}
\hline $\begin{array}{l}\text { Extracts/ } \\
\text { compounds }\end{array}$ & $\begin{array}{l}\text { Inhibition } \\
\text { parameters }\end{array}$ & $\begin{array}{c}\text { Vibrio } \\
\text { cholerae SG24(1) }\end{array}$ & $\begin{array}{c}\text { Vibrio } \\
\text { cholerae CO6 }\end{array}$ & $\begin{array}{c}\text { Vibrio } \\
\text { cholerae NB2 }\end{array}$ & $\begin{array}{c}\text { Vibrio } \\
\text { cholerae } \mathrm{PC} 2\end{array}$ & $\begin{array}{c}\text { Shigella } \\
\text { flexneri SDINT }\end{array}$ & $\begin{array}{c}\text { Staphylococcus } \\
\text { aureus ATCC } 25923\end{array}$ \\
\hline \multirow[t]{4}{*}{$\mathrm{MeOH}$ extract } & $\mathrm{MIC}$ & 512 & 256 & 256 & 256 & 128 & 64 \\
\hline & $\mathrm{MBC}$ & 512 & 512 & 256 & 512 & 128 & 128 \\
\hline & $\mathrm{MBC} / \mathrm{MIC}$ & 1 & 2 & 1 & 2 & 1 & 2 \\
\hline & $\mathrm{MIC}$ & 128 & 256 & 128 & 128 & 128 & 64 \\
\hline \multirow[t]{4}{*}{ EtOAc extract } & $\mathrm{MBC}$ & 256 & 256 & $>512$ & 256 & 128 & 128 \\
\hline & $\mathrm{MBC} / \mathrm{MIC}$ & 2 & 1 & / & 2 & 1 & 2 \\
\hline & $\mathrm{MIC}$ & 256 & 256 & 128 & 256 & 128 & 64 \\
\hline & $\mathrm{MBC}$ & 256 & $>512$ & 256 & 256 & 128 & 128 \\
\hline \multirow[t]{3}{*}{$n$-BuOH extract } & $\mathrm{MBC} / \mathrm{MIC}$ & 1 & l & 2 & 1 & 1 & 2 \\
\hline & $\mathrm{MIC}$ & $>256$ & $>256$ & $>256$ & $>256$ & 256 & 256 \\
\hline & $\mathrm{MBC}$ & / & / & / & / & $>256$ & $>256$ \\
\hline \multirow[t]{3}{*}{1} & $\mathrm{MBC} / \mathrm{MIC}$ & / & / & / & l & l & / \\
\hline & $\mathrm{MIC}$ & 128 & 64 & 64 & 64 & 16 & 16 \\
\hline & $\mathrm{MBC}$ & 128 & 64 & 64 & 128 & 32 & 16 \\
\hline \multirow[t]{3}{*}{2} & $\mathrm{MBC} / \mathrm{MIC}$ & 1 & 1 & 1 & 2 & 2 & 1 \\
\hline & MIC & 16 & 8 & 8 & 8 & 4 & 2 \\
\hline & $\mathrm{MBC}$ & 16 & 8 & 8 & 8 & 4 & 2 \\
\hline \multirow[t]{3}{*}{3} & $\mathrm{MBC} / \mathrm{MIC}$ & 1 & 1 & 1 & 1 & 1 & 1 \\
\hline & MIC & 128 & 64 & 64 & 128 & 64 & 32 \\
\hline & $\mathrm{MBC}$ & $>256$ & 128 & 64 & 256 & 64 & 32 \\
\hline \multirow[t]{3}{*}{4} & $\mathrm{MBC} / \mathrm{MIC}$ & / & 2 & 1 & 2 & 1 & 1 \\
\hline & $\mathrm{MIC}$ & 16 & 32 & 32 & 16 & 4 & 4 \\
\hline & $\mathrm{MBC}$ & 32 & 32 & 32 & 16 & 8 & 8 \\
\hline \multirow[t]{3}{*}{6} & $\mathrm{MBC} / \mathrm{MIC}$ & 2 & 1 & 1 & 1 & 2 & 2 \\
\hline & $\mathrm{MIC}$ & $>256$ & 256 & 256 & 256 & 128 & 128 \\
\hline & $\mathrm{MBC}$ & / & $>256$ & $>256$ & $>256$ & $>256$ & 128 \\
\hline \multirow[t]{3}{*}{7} & $\mathrm{MBC} / \mathrm{MIC}$ & / & / & I & l & / & 1 \\
\hline & MIC & 128 & 256 & 128 & 128 & 128 & 64 \\
\hline & $\mathrm{MBC}$ & $>512$ & 256 & 256 & 256 & 128 & 64 \\
\hline \multirow[t]{3}{*}{8} & $\mathrm{MBC} / \mathrm{MIC}$ & / & 1 & 2 & 2 & 1 & 1 \\
\hline & MIC & 256 & 128 & 128 & 128 & 64 & 64 \\
\hline & $\mathrm{MBC}$ & $>256$ & 256 & 128 & 256 & 128 & 64 \\
\hline \multirow[t]{3}{*}{9} & $\mathrm{MBC} / \mathrm{MIC}$ & / & 2 & 1 & 2 & 2 & 1 \\
\hline & MIC & 256 & 256 & 256 & 256 & 128 & 128 \\
\hline & $\mathrm{MBC}$ & $>256$ & $>256$ & $>256$ & $>256$ & $>256$ & 128 \\
\hline \multirow[t]{3}{*}{10} & $\mathrm{MBC} / \mathrm{MIC}$ & / & / & I & I & l & 1 \\
\hline & $\mathrm{MIC}$ & 16 & 16 & $>512$ & $>512$ & $>512$ & 4 \\
\hline & $\mathrm{MBC}$ & 16 & 16 & $>512$ & $>512$ & $>512$ & 4 \\
\hline \multirow[t]{3}{*}{ Ampicillin } & $\mathrm{MBC} / \mathrm{MIC}$ & 1 & 1 & l & l & / & 1 \\
\hline & $\mathrm{MIC}$ & 0.5 & 2 & 0.5 & 0.5 & 16 & 2 \\
\hline & $\mathrm{MBC}$ & 4 & 16 & 4 & 4 & 128 & 8 \\
\hline Tetracycline & MBC/MIC & 8 & 8 & 8 & 8 & 8 & 4 \\
\hline
\end{tabular}

/: not determined; MIC: Minimum Inhibitory Concentration; MBC Minimum Bactericidal Concentration.

previous findings $(42,43)$. All of the compounds that were found to be active in the present study are members of the triterpenoid, flavonoid, and phenolic acid groups. Although triterpenoid, flavonoid, and phenolic acid compounds have been reported to possess antibacterial activity $(39,44)$, no study has reported the activity of compounds $\mathbf{3}$ and 6-10 on the types of MDR pathogenic bacterial strains used in the present study.

The mechanism of action of terpenoids $(\mathbf{1}, \mathbf{2}, \mathbf{5}$, and 7-10) is not fully understood, but it may involve membrane disruption by lipophilic compounds (45). Inhibition of the tested bacterial strains by phenolic acid (4) may be due to iron deprivation or hydrogen bounding with vital proteins such as microbial enzymes (46). The mechanism of action of flavonoids (3 and 6) is still to be studied; nevertheless, their activity is probably due to their ability to form complexes with extracellular and soluble proteins and to form complexes with bacterial cell wall components. Moreover, lipophilic flavonoids may also disrupt microbial membranes (47).

\subsection{Antioxidant activity}

The $\mathrm{MeOH}$, EtOAc, and $n$ - $\mathrm{BuOH}$ extracts and their isolated compounds were evaluated for their antioxidant activity using two in vitro models. The results were expressed as the gallic acid equivalent antioxidant capacity of tested samples (Figure 2) and as equivalent concentrations of test samples scavenging $50 \%$ of the DPPH radical (Figure 3). DPPH ${ }^{*}$ and $\mathrm{ABTS}^{\circ+}$ radical scavenging activity were observed in all of the extracts. The $\mathrm{MeOH}$ and EtOAc extracts showed the most potent 


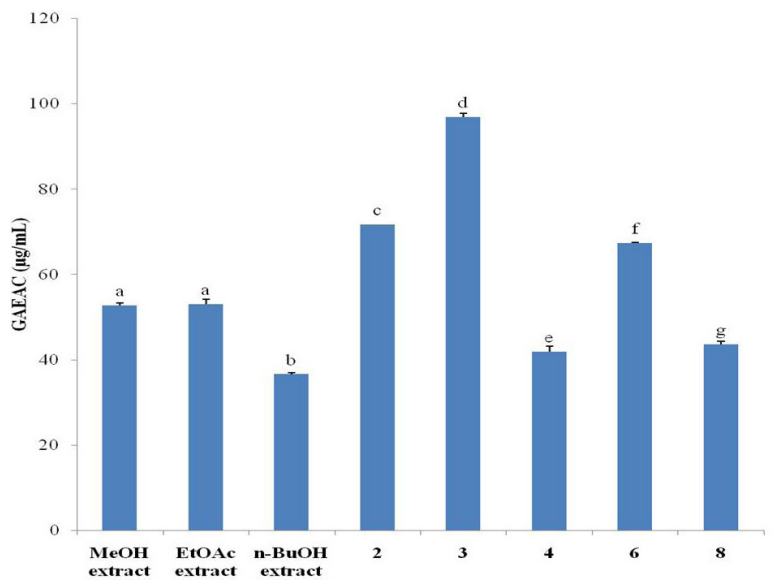

Figure 2. Gallic acid equivalent antioxidant capacity $($ GAEAC; $\mu \mathrm{g} / \mathrm{mL}$ ) of tested samples. Bars represent the mean \pm S.D. of three independent experiments carried out in triplicate. Letters a-e indicate significant differences between samples according to one-way ANOVA and the Waller Duncan test; $p<0.05$. Compounds $\mathbf{1}, \mathbf{5}, \mathbf{7}, \mathbf{9}$, and $\mathbf{1 0}$ were not active (results not shown)

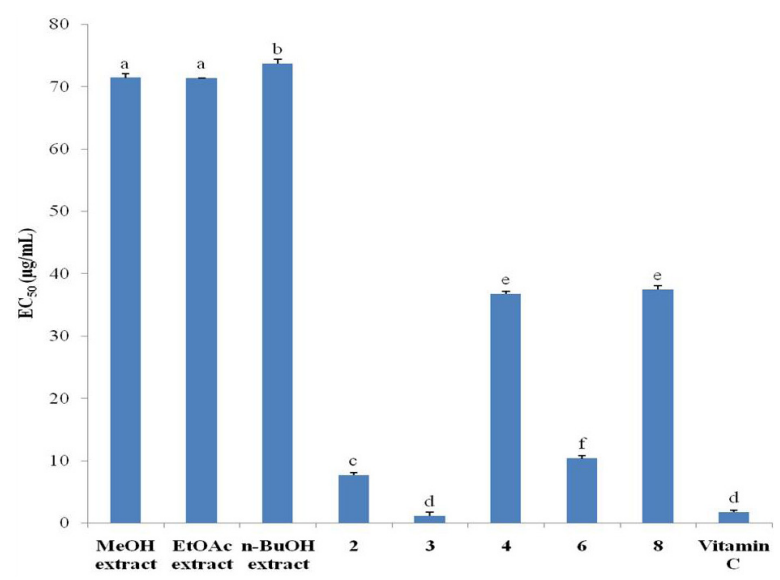

Figure 3. Equivalent concentrations of test samples scavenging $50 \%$ of the DPPH radical $\left(\mathbf{E C}_{50}\right)$. Bars represent the mean \pm S.D. of three independent experiments carried out in triplicate. Letters a-f indicate significant differences between samples according to one-way ANOVA and the Waller Duncan test; $p<0.05$. Compounds $\mathbf{1 , 5 , 7 , 9}$, and $\mathbf{1 0}$ were not active (results not shown).

activity, followed by the $n-\mathrm{BuOH}$ extract (Figures 2 and 3). These results indicate the potential of the tested extracts to serve as a natural source of antioxidants with the potential to reduce oxidative stress and provide subsequent health benefits. The antioxidant capacity of the tested extracts may be due to the hydrogendonating ability of phenols and flavonoids present in those extracts. Similarly, previous studies have reported that phenolic compounds contribute significantly to the antioxidant activity of medicinal plants $(39,48)$. The compounds that had the most potent $\mathrm{DPPH}^{\circ}$ and $\mathrm{ABTS}^{\text {++ }}$ radical scavenging activity were compounds 2 $\left(\mathrm{EC}_{50}=7.66 \mu \mathrm{g} / \mathrm{mL} ;\right.$ GAEAC $\left.=71.64 \mu \mathrm{g} / \mathrm{mL}\right), 3\left(\mathrm{EC}_{50}\right.$ $=1.09 \mu \mathrm{g} / \mathrm{mL} ; \mathrm{GAEAC}=96.88 \mu \mathrm{g} / \mathrm{mL})$, and $\mathbf{6}\left(\mathrm{EC}_{50}\right.$ $=10.34 \mu \mathrm{g} / \mathrm{mL} ; \operatorname{GAEAC}=67.35 \mu \mathrm{g} / \mathrm{mL}$ ), while the other compounds (compounds $\mathbf{4}$ and $\mathbf{8}$ ) had moderate antioxidant properties. Compounds $\mathbf{1}, \mathbf{5}, \mathbf{7}, \mathbf{9}$, and $\mathbf{1 0}$ were found to be inactive in both models. Compound 3 was the most potent antioxidant compound and its $\mathrm{DPPH}^{\circ}$ radical scavenging activity was equal to that of vitamin $\mathrm{C}$, which was used in the present study as reference antioxidant. This finding suggests that compound $\mathbf{3}$ is the best candidate to combat diseases associated with oxidative stress. This is very promising in terms of discovering antioxidants from plants. The antioxidant activity of compounds $\mathbf{2}$ and $\mathbf{4}$ agreed with previously reported findings $(42,49)$. However, the present study is the first to document the antioxidant activity of the $\mathrm{MeOH}$, EtOAc and $n$-BuOH extracts of $L$. leptocarpa as well as that of compounds $\mathbf{3 , 6}$, and $\mathbf{8}$.

\section{Conclusion}

Results indicated that $\mathrm{MeOH}$ and EtOAc extracts of $L$. leptocarpa as well as compounds $\mathbf{2 ,} \mathbf{3}$, and $\mathbf{6}$ possess the most potent antibacterial and antioxidant properties among the tested extracts and compounds. L. leptocarpa has the potential to be a natural source of products with health benefits, so it warrants further investigation.

\section{Acknowledgements}

The study was supported in part by the University of Dschang and the Cameroonian Ministry of Higher Education.

\section{References}

1. Fennell CW, Lindsey KL, McGaw LJ, Sprag SG, Staffort GI, Elgorashi EE, Grace OM, Van Staden J. Assessing African medicinal plants for efficacy and safety: Pharmacological screening and toxicity. J Ethnopharmacol. 2004; 94:205-217.

2. Taneja N, Kaur J, Sharma K, Singh M, Kalra JK, Sharma NM, Sharma M. A recent outbreak of cholera due to Vibrio cholerae O1 Ogawa in and around Chandigarh, north India. Indian J Med Res. 2003; 117:243-246.

3. Shikanga OT, Mutonga D, Abade M, Amwayi S, Ope M, Limo H, Mintz ED, Quick RE, Breiman RF, Feikin DR. High mortality in a cholera outbreak in western Kenya after post-election violence in 2008. Am J Trop Med Hyg. 2009; 81:1085-1090.

4. Sasaki S, Suzuki H, Fujino Y, Kimura Y, Cheelo M. Impact of drainage networks on cholera outbreaks in Lusaka, Zambia. Am J Public Health. 2009; 99:19821987.

5. World Health Organization. Cholera: Global surveillance summary, 2008. Wkly Epidemol Rec. 2009; 84:307-324.

6. Bhattacharya SK, Bhattacharya MK, Nair GB, Dutta D, Deb A, Ramamurthy T, Garg S, Saha KP, Dutta P, Moitra A, Mandal BK, Shimada T, Takeda Y, Deb BC. Clinical profile of acute diarrhoea cases infected with the new epidemic strain of Vibrio cholerae O139: dDesignation of the disease as cholera. J Infect. 1993; 27:11-15.

7. Kaper JB, Morris JG, Levine MM. Cholera. Clin Microbiol Rev. 1995; 8:48-86. 
8. World Health Organisation (WHO). Weekly epidemiological record. Cholera. 2010; 86:325-340.

9. Zwane PA, Kremer M. What works in fighting diarrheal diseases in developing countries? A critical review. The World Bank Res Observer. 2007; 22:1-24.

10. Cariri FA, Costa AP, Melo CC, Theophilo GN, Hofer E, de Melo Neto OP, Leal NC. Characterization of potentially virulent non-O1/non-O139 Vibrio cholerae strains isolated from human patients. Clin Microbiol Infect. 2010; 16:6267.

11. Lipp EK, Huq A, Colwell RR. Effects of global climate on infectious disease: The Cholera Model. Clin Microbiol Rev. 2002; 15:757-770.

12. Rice LB. Unmet medical needs in antibacterial therapy. Biochem Pharmacol. 2006; 71:991-995.

13. Borris RP. Natural products research: Perspectives from a major pharmaceutical company. J Ethnopharmacol. 1996 51:29-38.

14. Osman K, Evangelopoulos D, Basavannacharya C, Gupta A, McHugh TD, Bhakta S, Gibbons S. An antibacterial from Hypericum acmosepalum inhibits ATP-dependent MurE ligase from Mycobacterium tuberculosis. Int J Antimicrob Agents. 2012; 39:124-129.

15. Cai Y, Luo Q, Sun M, Corke H. Antioxidant activity and phenolic compounds of 112 traditional Chinese medicinal plants associated with anticancer. Life Sci. 2004; 74:21572184.

16. Özen T, Çöllü Z, Korkmaz H. Antioxidant properties of Urtica pilulifera root, seed, flower, and leaf extract. J Med Food. 2010; 13:1224-1231.

17. Oziegbe M, Faluyi JL. Reproductive biology of Ludwigia leptocarpa and $L$. adscendans subsp. Diffusa in Ile Ife, Nigeria. Turk J Botanic. 2012; 36:162-173.

18. Burkill HM. The useful plants of West Tropical Africa. 2nd Edition. Volume 4, Families M-R. Royal Botanic Gardens, Kew, Richmond, United Kingdom, 1997; pp. 969.

19. Averett JE, Zardini EM, Hoch PC. Flavonoid systematic of ten sections of Ludwigia (Onagraceae). Biochem. Syst Ecol. 1990; 18:529-532.

20. Mabou FD, Foning TPL, Ngnokam D, Harakat D, Voutquenne-Nazabadioko L. Leptocarposide: A new triterpenoid glycoside from Ludwigia leptocarpa (Onagraceae). Magn Reson Chem. 2014; 52:32-36.

21. Mabou FD, Ngnokam D, Harakat D, VoutquenneNazabadioko L. New oleanane-type saponins : Leptocarposide B-D, from Ludwigia leptocarpa (Onagraceae). Phytochem Lett. 2015; 14:159-164.

22. Oyedeji O, Oziegbe M, Taiwo FO. Antibacterial, antifungal and phytochemical analysis of crude extracts from the leaves of Ludwigia abyssinica A. Rich. and Ludwigia decurrens Walter. J Med Plant Res. 2011; 5:1192-1199.

23. Yakob HK, Sulaiman SF, Uyub AM. Antioxidant and antibacterial activity of Ludwigia octovalvis on Escherichia coli $\mathrm{O} 157: \mathrm{H} 7$ and some pathogenic bacteria. World Appl Sci J. 2012; 16:22-29.

24. Bag PK, Bhowmik P, Hajra TK, Ramamurthy T, Sarkar P, Majumder M, Chowdhury G, Das SC. Putative virulence traits and pathogenicity of Vibrio cholerae non-O1, non-O139 isolated from surface waters in Kolkata, India. Appl Environ Microb. 2008; 74:5635-5644.

25. Thakurta P, Bhowmik P, Mukherjee S, Hajra TK, Patra A, Bag PK. Antibacterial, antisecretory and antihemorrhagic activity of Azadirachta indica used to treat cholera and diarrhea in India. J Ethnopharmacol. 2007; 111:607-612.

26. Acharyya S, Sarkar P, Saha DR, Patra A, Ramamurthy T, Bag PK. Intracellular and membrane damaging activities of methyl gallate isolated from Terminalia chebula against multi-drug resistant Shigella species. J Med Microbiol. 2015; 64:901-909.

27. NCCLS. Methods for dilution antimicrobial susceptibility tests for bacteria that grow aerobically. Approved standards, M7-A4. National Committee for Clinical Laboratory Standards, Wayne, PA, 1997.

28. NCCLS. Methods for determining bactericidal activity of antimicrobial agents. Approved guideline, M26-A. National Committee for Clinical Laboratory Standards, Wayne, PA, 1999.

29. Brand-Williams W, Cuvelier M, Berset C. Use of a free radical method to evaluate antioxidant activity. LWT Food Sci Technol. 1995; 28:25-30.

30. Rice-Evans C, Miller NJ. Total antioxidant status in plasma and body fluids. Methods Enzymol. 1994; 234:279-293.

31. Mot AC, Pârvu M, Damian G, Irimie FD, Darula Z, Medzihradszky KF, Brem B, Silaghi-Dumitrescu R. A "yellow" laccase with "blue" spectroscopic features, from Sclerotinia sclerotiorum. Process Biochem. 2012; 47:968975.

32. Kundu AP, Mahato SB. Triterpenoids and their glycosides from Terminalia chebula. Phytochemistry. 1993; 32:9991002.

33. Messi BB, Ndjoko-Ioset K, Hertlein-Amslinger B, Meli A, Nkengfack AE, Wolfender JL, Hostettmann K, Bringmann G. Preussianone, a new flavanone-chromone biflavonoid from Garcinia preussii Engl. Molecules. 2012; 17:61146125.

34. Marzouk MS, Moharram FA, El-Dib RA, El-Shenawy SM, Tawfike AF. Polyphenolic profile and bioactivity study of Oenothera speciosa Nutt aerial parts. Molecules. 2009; 14:1456-1467.

35. Ayinampudi SR, Ramchander M, Thirupathaiah AA. New Triterpene from Ludwigia hyssopifolia (G. Don) Exell. Int J Chem Tech Res. 2013; 5:342-346.

36. Koeppen BH. C-Glycosylflavonoids. The chemistry of orientin and iso-orientin. Biochem J. 1965; 97:444-448.

37. Dabur R, Gupta A, Mandal TK, Singh DD, Bajpai V, Gurav AM, Lavekar GS. Antimicrobial activity of some Indian medicinal plants. Afr J Trad CAM. 2007; 4:313-318.

38. Oyedeji O, Taiwo FO, Ayinde FO, Ajayi OS, Oziegbe $\mathrm{M}$, Kelani MT, Adewole AH. In vitro antimicrobial and antioxidant analysis of gallic acid from the leaves of Ludwigia abyssinica A. Rich. European J. Med. Plants. 2014; 4:1098-1112.

39. Djouossi MG, Tamokou J-de-D, Ngnokam D, Kuiate JR, Tapondjou AL, Harakat D, Nazabadioko LV. Antimicrobial and antioxidant flavonoids from the leaves of Oncoba spinosa Forssk. (Salicaceae). BMC Compl Altern Med. 2015; 15:134.

40. Kuete V. Potential of Cameroonian plants and derived products against microbial infections: A review. Planta Med. 2010; 76:1479-1491.

41. Kuete V, Efferth T. Cameroonian medicinal plants: Pharmacology and derived natural products. Front Pharmacol. 2010; 1:123.

42. Wansi JD, Chiozem DD, Tcho AT, Toze FA, Devkota KP, Ndjakou BL, Wandji J, Sewald N. Antimicrobial and antioxidant effects of phenolic constituents from Klainedoxa gabonensis. Pharm Biol. 2010; 48:1124-1129. 
43. Simpol L, Dayrit F, Abe F, Yamauchi T. Isolation of maslinic acid from the leaves of Bixa orellana. Philippine J Sci. 1993; 118:147-166.

44. Garcia A, Bocanegra-Garcia V, Palma-Nicolas JP, Rivera G. Recent advances in antitubercular natural products. European J Med Chem. 2012; 49:1-23.

45. Termentzi A, Fokialakis N, Skaltsounis AL. Natural resins and bioactive natural products thereof as potential antimicrobial agents. Curr Pharm Des. 2011; 17:12671290.

46. Scalbert A. Antimicrobial properties of tannins. Phytochemistry. 1991; 30:3875-3883.

47. Cowan MM. Plant product as antimicrobial agents. Clini
Microb Rev. 1999; 12:564-582.

48. Tatsimo NSJ, Tamokou J-de-D, Havyarimana L, Csupor Dezső, Forgo P, Hohmann J, Kuiate JR, Tane P. Antimicrobial and antioxidant activity of kaempferol rhamnoside derivatives from Bryophyllum pinnatum. BMC Res Notes. 2012; 5:158.

49. Montilla MP, Agil A, Navarro MC, Jiménez MI, GarcíaGranados A, Parra A, Cabo MM. Antioxidant activity of maslinic acid, a triterpene derivative obtained from Olea europaea. Planta Med. 2003; 69:472-474.

(Received June 13, 2016; Revised June 17, 2016; Accepted June 21, 2016) 